\title{
Shooting for fame: Spectacular youth, web 2.0 dystopia, and the celebrity anarchy of generation mash-up
}

\author{
Michael Serazio \\ Fairfield University, mserazio@fairfield.edu
}

Follow this and additional works at: https://digitalcommons.fairfield.edu/communications-facultypubs Copyright 2010 Wiley-Blackwell.

This is a pre-print of an article accepted for publication in Communication, Culture, \& Critique (3, $3,2010)$. The definitive version is available at www3.interscience.wiley.com.

\section{Repository Citation}

Serazio, Michael, "Shooting for fame: Spectacular youth, web 2.0 dystopia, and the celebrity anarchy of generation mash-up" (2010). Communication Faculty Publications. 13.

https://digitalcommons.fairfield.edu/communications-facultypubs/13

\section{Published Citation}

Serazio, Michael. 2010. Shooting for fame: Spectacular youth, web 2.0 dystopia, and the celebrity anarchy of generation mash-up. Communication, Culture, \& Critique 3 (3) 416-434.

This item has been accepted for inclusion in DigitalCommons@Fairfield by an authorized administrator of DigitalCommons@Fairfield. It is brought to you by DigitalCommons@Fairfield with permission from the rightsholder(s) and is protected by copyright and/or related rights. You are free to use this item in any way that is permitted by the copyright and related rights legislation that applies to your use. For other uses, you need to obtain permission from the rights-holder(s) directly, unless additional rights are indicated by a Creative Commons license in the record and/or on the work itself. For more information, please contact digitalcommons@fairfield.edu. 
Running Head: SHOOTING

Shooting for Fame:

Spectacular Youth, Web 2.0 Dystopia, and the Celebrity Anarchy of Generation Mash-Up

Deleted: Notorious 


\begin{abstract}
In this essay, I analyze the emergent phenomenon of infamous youth shooters at the

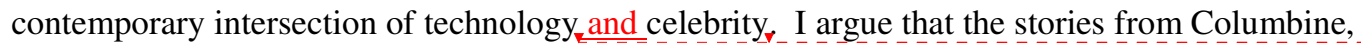
Virginia Tech and Jokela High School in Finland, betray a disconcerting dystopia of userDeleted: Deleted: and postmodernity Deleted: , generated content gone wrong at a moment of much Web 2.0 hype. I use their actions and the subsequent reaction to these tragedies as case study portals into an era of celebrity anarchy and narcissistic youth. This analysis draws from a theoretic framework synthesizing historical perspectives on fame and probing the function of celebrity in late modernity. I then contextualize these youth shooters within a generational context of purported narcissismsuggesting that their attacks are both premeditated (planned in advance) as well as pre-mediated Deleted: and postmodern fluidity Deleted: mediatated (packaged in advance). I focus particularly closely on the mash-up material posted online by the Deleted: directed world's first "YouTube killer" from Finland to contend that these texts can be read as perverse reclamation of agency and spectacle. I conclude by pondering the challenges that journalism faces in complying with the youth shooter's demand for celebrity and the possibility that, in the self-broadcasting world of Web 2.0, their role as gatekeepers may be more confounded than ever.
\end{abstract}


Introduction

In an introduction to his exploration of the economics of fame, Tyler Cowen (2000)

quotes the following declaration by British author Samuel Johnson:

Every man... has some project by which he hopes to rise to reputation; some art by which he imagines that the world will be attracted; some quality, good or bad, which discriminates him from the common herd of mortals, by which others may be persuaded to love, or compelled to fear him. (vii)

Johnson far predated the troubling rise of youth shooters who have intermittently unleashed school massacres at the turn of the $21^{\text {st }}$ century. Each time, observers seem to inquire

Deleted: bystanders

Deleted: reopen lines of inquiry into the cause of their actions with familiar bewilderment: Who is to shoulder the blame for these recurring attacks? Debate quickly ignites over the tools of the tragedy - with gun control advocates faulting availability and NRA surrogates countering with a case for mutually assured deterrence. The media - both singular and plural - is/are routinely taken to task, as well as the culture(s) fostered. Following the 1999 Columbine killings, pundits invoked targets both specific and broad: Marilyn Manson and goth music subculture; The Matrix and violent action movies; the Doom video game series and Internet technology writ large. Conservatives incorporated the violence into a larger (culture) war: Congressional leader Newt Gingrich "credited the hippie embrace of freedom of the 1960s, while Thomas Sowell argued that the 1960s exonerated individuals from responsibility... [and] Tom DeLay just blamed daycare, the teaching of evolution, and "working mothers who take birth control pills"” (Kimmel, 2008, p. 66). More recently, in the wake of the Virginia Tech tragedy, crusader Jack Thompson loudly scourged gaming as the media culprit, though no evidence from Seung-Hui Cho's background was found to validate these claims (Hartlaub, 2007). As Douglas Kellner (2008) notes, "just 
about every form of youth culture except bowling" gets hauled in for moral questioning after an incident such as that of Columbine, Virginia Tech or Pekka-Eric Auvinen's less infamous rampage in Tuusula, Finland ${ }^{1}$ (p. 48).

That the politicization of school shootings often puts the rhetorical cart before the empirical horse should be of little surprise to any observer of mediated politics. Yet even the

Deleted: (

Deleted: )

Deleted: (

Deleted: )

existence - or lack thereof - of demonstrable evidence about media effects on youth shooters

misses a broader point. This sort of lay theorizing constructs audiences (particularly youth

audiences) in the oldest of "mass society" frames ${ }^{2}$ : vulnerable and passive, at a juncture

"characterized by the breakdown of traditional social responsibilities and ties, leading to a mass

of alienated individuals who could be led or controlled" (Brooker \& Jermyn, 2003, p. 5). Led,

controlled, or induced by media message to violent rampage - in this essay, I will argue that this

critique seems to get it only half right. If we are to take Eric Harris, Dylan Klebold, Seung-Hui

Cho and Pekka-Eric Auvinen as symbols of contemporary youth (as media commentary is often

wont to treat them), they are indeed vulnerable - but not in a hypodermic way - and far from

passive. Rather, their stories betray a disconcerting dystopia of user-generated content gone

wrong. Media indeed functioned as tools of the tragedy in this telling, but these tools are wielded by the killers themselves as much as by professional broadcasters. To recall Elihu

${ }^{1}$ 18-year-old Auvinen's murder-suicide rampage at Jokela High School, just north of Helsinki, on November 7, 2007, left 8 victims and Auvinen himself dead. Besides being the deadliest act of school violence in Finnish history to that point, it achieved notoriety for the fact that Auvinen had publicized the incident on YouTube immediately prior to the attack and had posted abundant material online even pefore that, earning him the nickname, "the YouTube killer."

Deleted: increasingly

Deleted: powerful

Deleted: Indeed, the question seems to be as much what do youth shooters do with, to, and through media as what do media do to youth shooters - to

Deleted: before

Deleted: prior to

${ }^{2}$ Ellen Seiter (1999) offers an interesting exploration contrasting "the 'weak' theory of media effects held by cultural studies academics, by many industry professionals, and proposed in [her] own work on children's television (Seiter, 1983) with the theories of 'strong' effects that were often implicit in conversations I had with teachers and childcare professionals" (p. 59). Political leaders seem to similarly dote on "strong" effects rhetoric in the wake of school shootings. 
Katz's (2001) discipline-synthesizing epigram, we might inquire jnto what youth shooters do to, with, and through media as much as what media do to youth shooters, For in shooters' quest for notoriety, those mass media broadcasters seem to be held hostage (metaphorically) along with shooters' classmates (literally). And while Samuel Johnson may have predated school shootings by 300 years, his declaration no doubt prefigured the same abiding and timeless fame impulse

\begin{tabular}{|l|}
\hline Deleted: as \\
\hline Deleted: \\
\hline Deleted: (2001) \\
\hline Deleted: I \\
\hline Deleted: their \\
\hline Deleted: the \\
\hline Deleted: "powerful" \\
Deleted: " \\
\hline
\end{tabular}
that still drives these actions at a moment when new technologies and cultural conditions of late modernity are destabilizing the media landscape and giving way to a kind of celebrity anarchy to be seized upon by enterprising Web 2.0 terrorism. Harris and Klebold's home videotapes, Cho's NBC multimedia package and, most emblematically, Auvinen's YouTube mash-ups signal youth audiences armed with new media participatory software (Bruns, 2008; Deuze, 2007; Jenkins, 2006) and suckled in an allegedly narcissistic climate (Twenge, 2006)

The dizzying convergence of producer and consumer vis-à-vis media content as the digital generation comes of age has introduced a new scale, pace or pattern of perception into human affairs (McLuhan, 1964). Troubled youth like Cho and Auvinen perhaps develop their "sense ratios" in this technological context. Pundits have invested much effort in trying to decode the meta-message about this youth era that those shooters send with firearms. To date, not enough analysis has critically appraised the message sent by way of their cameras themselves. What, therefore, are youth shooters trying to communicate through their actions about celebrity and technology? And how is journalism supposed to respond?

\section{Fame and Function}

By regularly supplying audiences with an appetite for the visual, $20_{\perp}^{\text {th }}$-century media and television in particular - cultivated audiences with steady wonderment for the possibility of

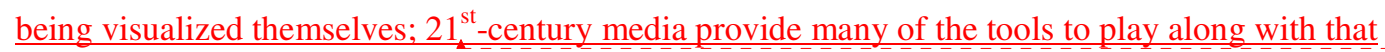

\begin{tabular}{l} 
Deleted: \\
Deleted: and postmodernity \\
Deleted: creating \\
Deleted: an \\
Deleted: twentieth \\
Dormatted: Superscript \\
Deleted: created \\
Deleted: an \\
\hline Formatted: Superscript \\
\hline
\end{tabular}

Deleted: And Yet yet something remains fundamentally different about mass media and user-generated media in the context of fame-seeking behaviors.

Deleted: potentially

Deleted: as much

Deleted: as with handguns

Deleted: that compels them to use both

Deleted: As Lance Strate (2007) notes on his blog:II

Guns and cameras are both media of

communication, as [Marshall] McLuhan

makes clear... Both guns and cameras are extensions of the human body, guns

extending the fist and fingernail in their

offensive capacities, cameras extending

the eyes in their voyeuristic capacities...

Guns and cameras are both methods by

which people communicate, sending

messages to their target and to bystanders alike.II 
$\underline{\text { fantasy. }}$ This, it would seem, is one of the "big picture" effects of television on society over the course of the past fifty years: It exponentially accelerated our cult of fame - that pervasive and

Deleted: , if not created, a inveterate desire for personal celebrity that shows up embarrassingly on reality TV, gauchely in one's thousands of MySpace "friends," and most gruesomely in the work of Cho and Auvinen that is at once destructive and creative. These media have, in a way, made fame the dominant currency of modern social capital. They have brought the stage, in this most general sense, to the forefront of human consciousness

This may be a less explored implication of cultivation theory and agenda-setting research. $\underline{\text { If, indeed, television viewing cultivates perceptions of social reality - and research has notably }}$ found that heavier viewers tend to see the world, for example, as more dangerous - then perhaps $\underline{\text { the gradual, accumulated exposure to mass media similarly breeds a tendency to value fame for }}$ its own sake. In their review of three decades of cultivation research, Michael Morgan, James Shanahan and Nancy Signorielli (2009), state that, "Cultivation is not conceived as a

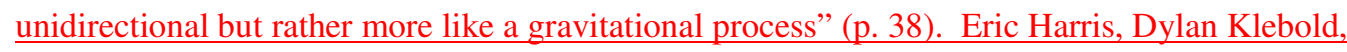
$\underline{\text { Seung-Hui Cho and Pekka-Eric Auvinen were perhaps vulnerable to that sense of "gravity" as }}$ much as the individual messages they received from rock stars or hit films. For no matter what

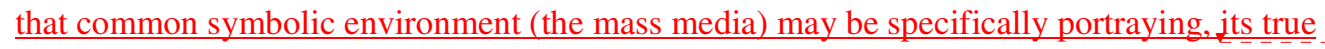
power is in convincing viewers of the continuing importance of whatever topics and persons pass through its screens. The gravitationalpull exerted on (and perhaps internalized by) viewers is one of relevance - that what shows up on-screen, whether it be violence or altruism, fundamentally matters. Thus, the cultivated effect of mass media on audiences may be to ingrain $\underline{\text { an altered sense of "worth ratios" as much as McLuhan's "sense ratios" - and by this, I mean }}$ $\underline{\text { that visual media cultivate an appreciation of spectacle as success, The loftiest ideal for an }}$

Deleted: , in their review of three decades of cultivation research over three decades,

Deleted: declare

Deleted: The point is c

Deleted: N

Deleted: TV's

Deleted: “
Deleted: "
Deleted: that
Deleted: (
Deleted: )
Deleted: long-term


individual in a society governed by agenda-setting media (e.g. McCombs \& Shaw, 1972) is to set or be on the agenda (something that only fame affords): That is, as we are variously told what to think about, we crave most to be thought about ourselves. Thus, Marilyn Manson's true danger to the youth shooter is perhaps not in what he says, but in his capacity to be heard. To that end, literary and social historian Leo Braudy (1986) notes that this sense of "performance" has overtaken the nation-state, God, and even history itself, as the dominant frame for assessing achievement: "Much more than the famous of any previous century, the famous of the twentieth century, whether in public professions or not, are onstage" (p. 549, italics in original).

Dramaturgical sociology notwithstanding (e.g., Goffman, 1959), literal stages used to be more stable, clearly delimited places. We knew where to find them and how to avoid them;

Shakespeare's cliché ("all the world's a stage”) was more metaphor than camera-phone fact.

Fame, too, has seen less volatile days. Braudy's tome, The Frenzy of Renown, provides a comprehensive survey of this condition through the ages and the needed back-story for shooter celebrity. The prospect of fame surely weighed less heavily on an individual's soul jn the

Middle Ages, a period of strict social hierarchy and deterministic, inherited ties. The emergence of modernity - and the creeping schizophrenia of identity - yoked the yearning to be known with the uncertainty of the self; with industrialization and urbanization, fewer traditions and more mobility meant that fame had more existential utility than when a fixed order constrained, if not altogether obscured, those stirrings of ambition: "As each new medium of fame appears, the human image it conveys is intensified and the number of individuals celebrated expands" (Braudy, 1986, p. 4). Some might say this alludes to a fragmentation or even democratization of fame; others note that achievement and eminence now have "pseudo" relations (Boorstin, 1987). Cowen (2000) remarks on how the media machinery of late modernity seems to grant fame 
without consulting merit: "As markets distribute fame more widely and more diversely, most fame rewards will stand apart not only from merit but from any particular standard” (p. 101, italics in original). Paris Hilton springs to mind - our "human pseudo event" in full. Because of this, critics curse fame for its complicity with neoliberal capitalism and P. David Marshall (1997) Deleted: - both metaphorical and literal in particular condemns how "celebrity status became aligned with the potentialities of the wedding of consumer culture with democratic aspirations" (p. 9). But to understand why Harris, Klebold, Cho and Auvinen "pre-mediated" their attacks so deliberately, we might seek some synthesized typology of fame's functionality in the late modern imagination.

Indeed, there exists a distinctly existential logic underpinning their savage gambits. It is the idea that, in late modern society, the supposedly rootless, alienated individual can, through

visual media broadcast, rise above his or her station in life, his or her "seat in the audience"that fame can grant eternal life and one's own image proliferation can somehow transcend mortality. Before television, this was the vague, distant seduction of film fame; after television, it suddenly appeared open to more viewers; with the dawn of the Internet era (that Auvinen exploited so fiendishly), those studio walls have been further knocked down commencing a hyper-mobility of images sliding past had been the gatekeepers of yesteryear. To be known (and, by this, I mean "seen" - that occularcentric conversion of image to knowledge in the TV epoch) is to repair the plight and plague of late modernity. One might break down celebrity desire into a typology of three categories: It provides one with the experience of individuality; it offers transcendence above powerless anonymity; and it entices with the potential for immortality. These will help illuminate the logic behind the mediated productivity of the youth shooters; these are the "worth ratio" values cultivated by decades of mass media ritual.

Deleted: problem

Deleted: fully

Deleted: that punctures olderformer and a lack of gatekeeping technology 
Marshall (1997) illuminates the first concept quite clearly: "[Celebrities] are allowed to express themselves quite individually and idiosyncratically while the rest of the members of the population are constructed as demographic aggregates" (p. ix). The famous person, being granted wider leverage of psychosocial agency, has the power to construct his or her own identity and to "house conceptions of individuality" there (p. xi). Braudy (1986) adds, "In the heart of the fan and the famous alike, fame is a quiet place where one is free to be what one really is, one's true, unchanging essence" (p. 6). In short, fame delivers individuality; it offers identity expressed most forcefully against uncertainty. Auvinen seems to rage at this uncertainty, surprisingly explicitly, when he posts in his online manifesto:

Deleted: condition Collective deindividualization is a phenomenon where the individual will be trained as part of the mindless herd controlled by state, corporation, church or some other organization, group, ideology, religion or mass delusion system... It is just done so that people will think they are free and don't realize they are being enslaved. Majority of people in society are weak-minded and ignorant retards, masses that act like programmed robots and accept voluntary slavery.

Conservative pundits, as noted earlier, unknowingly rely upon a "mass society" critique to explain how individuals like Auvinen are warped by powerful media, but Auvinen himself reveals Frankfurt School-worthy angst here (Horkheimer \& Adorno, 1977).

By way of the camera - by way of circulating images of one's self as Cho and Auvinen did in advance of their acts - that anonymity of one's existence undergoes "legitimation," as Graeme Turner (2004) puts it (p. 62). David Giles (2000) notes how the camera itself is a critical step forward in this legitimation: "Each time we are photographed, it could be argued, we reproduce" (p. 51, italics in original). One can add that school shooters seeking celebrity status 
see this legitimation in reproduction An important ethical question journalism will need to answer in going forward is whether reproducing the media packages shooters provide renders complicity with this legitimation (and, indeed, if there's really any alternative in forgoing such information subsidies in an era of rampant self-publishing). Anonymity surely mattered far less in the pre-modern world; Braudy (1986) estimates that, in the medieval period, the average human being only saw 100 other people in their whole lifetime. One main effect of the escalating crowds encountered in daily life is "the blossoming of more contenders for symbolic singularity" (p. 27). To see so many faces is to trigger an unease of being unknown and hence powerless. Chris Rojek (2001) has suggested how, through para-social interaction, celebrities offer potent messages and affirmations to audiences, verifications that ultimately serve the functions once given over to religion. Yet para-social interaction also feeds the celebrity by articulating the pleasure taken in the celebrity's transcendence above powerless anonymity; it heralds the godhood potential that visually mediated fame suggests.

To this point, I've argued that visually mediated fame allures by first offering the individual the very possibility of individuality and, second, making that individuality known to all at a particular point in time. The third and final existential appeal of fame exists in the eternal dimension - along the $y$-axis - in its siren call to immortality. If fame has become the dominant currency of modern social capital, it is through this prism that one hopes for stability - to become a gold-standard across time. This Braudy (1986) documents, may be the oldest penchant of all: "In the ancient world the desire for fame is a desire to make an impact on time, to be remembered" (p. 27). Fame stood out as a way to cheat death; to be granted eternal life. Indeed, it was just as much a sense of being more than human: "For if an image lasts beyond death, it implies that its possessor is more than human" (p. 589). If in the first stage of this fame typology
Deleted: ;

\section{Deleted:}

Deleted: a

Deleted: their

Deleted: to that articulates

Deleted: , as is echoed in the Christian formulation 
singularity was sought and in the second ubiquity, in the third, we can add permanence. Giles (2000), citing psychologist Erik Erikson who coined the idea of "identity crisis," terms this basic desire "generativity" - that is, being able to affect successive generations (p. 44). The inevitable fear of copycat threats following a school shooting is a consequence of the shooters' egomaniacal yearning for generativity; at their most specific, they hope to inspire disciples through the publicity generated. Continuing Auvinen's manifesto from the earlier quote:

Deleted: explicit Deleted: specifically

Majority of people in society are weak-minded and ignorant retards, masses that act like programmed robots and accept voluntary slavery. But not me! I am self-aware and realize what is going on in society! I have a free mind! And I choose to be free rather than live like a robot or slave. You can say I have a 'god complex', sure... then you have a 'group complex'! Compared to you retarded masses, I am actually godlike.

Joseph Campbell believes this dimension of fame - immortality - was what endowed movie stars

Deleted: believed with their magical quality: "The person you are looking at [on screen] is somewhere else at the same time. That is the condition of the god" (in Gritten, 2002, p. 72). A century removed from Lumière - where countless screens seem to be open to countless faces - what gods do youth worship and where might it be leading them?

Deleted: ensconced in conditions that many observers describe as "postmodern,"

Deleted: seem

\section{Pre-Mediated Killing}

In 1898, a poll asked some 1,500 young teens, "What person of whom you have ever heard or read would you most like to resemble?" (Cowen, 2000, p. 47). George Washington topped the list, as did Abraham Lincoln, with 78 percent of selections coming from politicians, moral leaders, and military heroes. No entertainers appeared. A similar survey took place in 1948, with Franklin Roosevelt and Clara Barton taking the lead and 14 percent choosing entertainers. In 1986, The World Almanac listed the ten most admired figures by U.S. teenagers: 
Bill Cosby, Sylvester Stallone and Eddie Murphy led off a list wholly comprised of current or former entertainers (including, not irrelevantly, the U.S. president at the time).

Few would seemingly dispute that contemporary culture is fully immersed in the throes

of fame desire - as the historian Braudy (1986) comments, it is our "national obsession" (p. 8). We have more potential than ever to direct the spotlight of (now personal) media technologies in Deleted: With the costs of production whatever direction we choose and, tellingly, we shine them upon ourselves - arms outstretched, tools lowered, w

Deleted: it digital cameras turned inward. With MySpace, Facebook, and YouTube, fame - albeit a kind of micro-fame - seems to be delegated in remarkably egalitarian ways relative to a century ago, very nearly bordering on anarchy. Television presaged this shift in its evolution from film and the Internet seems to have accelerated the trend. Yet the visual technologies and media developments that "empower" - to borrow a fondly used cultural studies buzzword - the spectator are the same advances that cheapen the classical definition of fame and the elements that structure its stability. A generation - Cho and Auvinen's generation - is coming of age as the media landscape reshapes itself in profound ways.

$\underline{\text { Take, as one example, Morris Janowitz's classic definition of mass media which states: }}$ "Mass communications comprise the institutions and techniques by which specialized groups employ technological devices (press, radio, films, etc.) to disseminate symbolic content to large, heterogeneous and widely dispersed audiences" (cited in McQuail \& Windahl, 1993, p. 6). Yet it is not broadcasting but now the network that represents "the core organizing principle of this [new] communicative environment," as Axel Bruns (2008) proposes (p. 14). Since the popular emergence of Internet use some 15 years ago - when the network began to supplement if not supplant broadcasting as that dominant organizing model - user-generated media has steadily increased, thanks to lower costs of production equipment and easier means of distribution. Yet 
in contrast to mass media forms of the 20th century (centralized, professional content in

newspapers, on radio or in film), the user-generated content that has emerged in the past decade

(decentralized, amateur content on Blogger, YouTube, Facebook and Twitter) provides a

different experience of fame - quicker, cheaper - for those who produce it. In turn, user-

Deleted: U

generated fame tends to lack the depth, breadth and length of mass media fame and cheapens the

former's claims to singularity, ubiquity and permanence: what was once 15 minutes of fame to

all has perhaps been truncated to 15 seconds of fame to 15 people. Therefore, user-generated

Deleted: U

content allows users to act out the rhythms of mass media fame - broadcasting daily minutia to

our social networks and uploading Flickr streams as self-paparazzi - even if TMZ has little

interest in covering our lives. This kind of behavior might lend itself to a kind of rephrase of $U S$

Weekly: "Stars - we're just like them!"

Douglas Kellner (2008), in a book-length analysis devoted to school shootings, writes

that the Internet offers a social space markedly different from earlier media cultures - "more

fragmented, diverse, and interactive" and "an increasingly complex and hybridized matrix" (p.

67). The shootings offer performance as participatory spectacle and highlight the deeply

narcissistic vein that apparently pulses within millennial youth (and rages unchecked upon

Columbine, Virginia Tech and Jokela). Jean Twenge (2006) calls this group Generation Me for

precisely that reason: It represents, in her view, a demographic that harbors wildly entitled

expectations about the self and fame. The angst and alienation embodied in shooters' rage is

perhaps a product of that crushing gap between media-fueled fantasy and lived reality:

"GenMe's focus on the needs of the individual is not necessarily self-absorbed or isolationist;

instead it's a way of moving through the world beholden to few social rules and with the

unshakable belief that you're important" (p. 49). She cites various evidence that suggests youth

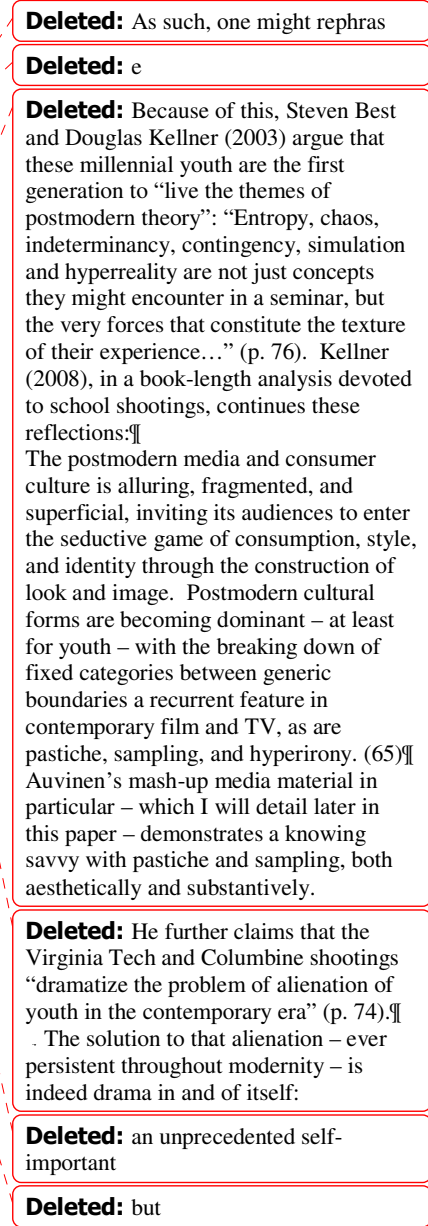


narcissism has grown by leaps and bounds in recent years; for instance, in the early 1950s, 12 percent of teens agreed with the survey statement, "I am an important person" as compared to 80 percent in the 1990s $(p .69)$. Other data show generational rises in "agency" as a youth personality trait (not to mention as an audience construct for media researchers in cultural studies): that is, "assertiveness, dominance, independence and self-promotion" (p. 74). Most notably for this analysis, thanks to decentralizing technology, the rise of reality media formats, and user-generated content platforms, Twenge suggests that "much of GenMe expects to be famous" (p. 87). To that end, Twenge points to a 2004 national survey that found more college freshman wanting to be an "actor or entertainer" than those who hoped to go into law, medicine, social work, business or teaching (p. 82). More recently, Pew (2007) found that, among 18- to 25-year-olds, being famous jis among the most important goals for their generation. ${ }_{-}^{3}$ These widespread aspirations stitch the social fabric of millennial youth; and yet it is equally marked by deep pockets of unease:

Other studies have confirmed that younger generations experience more anxiety and stress... The number of teens aged 14 to 16 who agreed that 'Life is a strain for me much of the time' quadrupled between the early 1950s and 1989... One out of three college freshmen reported feeling 'frequently overwhelmed' in 2001, twice as many as in the 1980s. (Twenge, p. 107)

These are the statistical measures typically invoked when contextualizing a school shooter run amok; yet these data on stress must not be extricated from the related data on fame (which is

${ }^{3}$ Again, cultivation research is especially well-positioned to explore this connection more empirically: Do heavier consumers of media value fame more? Is television's contribution to the viewer's sense of social reality a tilting of "worth ratios" in the direction of celebrity? Being a critical essay employing three case studies of youth shooter celebrity, the format here is not suited to answering these questions concretely, though future research would do well to explore these correlations in a more narrow, focused way.

Deleted: 80 percent of teens by the 1990s agreed with a survey measure inquiring about self-importance relative to 12 percent agreeing with it in the early $1950 \mathrm{~s}$

Deleted: Further

Deleted: and

Deleted: concludes

Deleted: For instance 
comparatively overlooked when appraising societal "causes" of, say, Columbine). The burdens of celebrity would appear to weigh on the youth imagination and, for shooters, can perhaps only be lifted with successful execution of the notorious act.

As such, Howard Stein (2000) claims that Columbine is a metaphor for the crisis of

"disposable youth.” I believe that Columbine - along with Virginia Tech and Jokela - is equally

Deleted: a metaphor for the crisis of celebrity and youth, of fame-seeking and identity-uncertainty. After all, evidence bears out the fact that schools are, by and large, very safe environs for youth despite the much-panicked coverage following a tragic incident (Muschert, 2007). Muschert also notes that there is, as yet, no unified body of knowledge or theory about school shootings. Ralph Larkin (2007), in an analysis focused on Columbine, also concedes "there is no comprehensive understanding as to why it happened and why it happened where it did" (p. 15). But he does suggest, importantly, that the contemporary cult of celebrity may be a striking factor: "One of the America

Deleted: contributing hallmarks of contemporary postmodern culture is the rise of an intensely competitive struggle within the cultural realm that can be distinguished from economic and political competition. Sitting at the top of this competitive struggle is the celebrity" (p. 180). Contextualizing these forces in terms of youth, Larkin argues, "In contemporary postmodern culture, the new class system can be categorized as celebrities, has-beens, and nobodies. The culture of the modern high school reflects that same sort of stratification in the microcosm" (p. 181). At Columbine, Larkin contends, jocks sat atop the social pyramid as micro-celebrities - and "everybody else is a nobody" (i.e. lacking the individuality fame affords). He adds:

To an impressionable adolescent, the message of postmodern American culture is that if you are not a somebody, then you must be a nobody, which is worse than being a has- 
been. At least if you are a has-been, you can be recycled on a 'whatever become of...' article or show. (192)

He quotes Donna Gaines' conclusion following an ethnographic inquiry into the teen culture that ended in a New Jersey suicide pact:

Kids who go for the prize now understand there are only two choices - rise to the top or crash to the bottom. Many openly admit they would rather end it all now than end up losers... The big easy or the bottomless pit, but never the everyday drone. As long as there are local heroes and stories, you can still believe you have a chance to emerge from the mass as something larger than life... kids try to play at being one in a million, some way of shining, even if it's just for a while. (151)

It is not difficult to hear in Auvinen's manifesto a similar disdain for that "everyday drone": "Of course there is a final solution [to this]: death of the entire human race," he writes. Besides the genocidal Nazi allusions here (hardly coincidental given the prominence of Nazi imagery and themes in his other materials), Auvinen's real solution is fame. Like Harris and Klebold before him, Auvinen hoped his action would satisfy what Erikson called "generativity": "There is a third way to become a celebrity - and that is to do something so outrageous that one becomes notorious. For nobodies, this is the one sure route to celebrity" (Larkin, p. 193).

Of course, as Kellner (2008) observes, media-made celebrity killers stretch back for

Deleted: four decades from political assassins like Lee Harvey Oswald to serial murders like the Zodiac killer and Son of Sam. The technologies of the digital era bring celebrity platforms inside so many more bedrooms of youth. The means are there to self-make into a celebrity killer; only the ends are needed. Robert Samuels (2000) believes that, because of this, school shooters are guided by contemporary entertainment logic endemic to "postmodern media narcissism": 
By constantly breaking down the distinctions between the private and the public, the audience and actor, and reality and fiction, postmodern media feed into a technological mode of narcissism where everyone has the potential opportunity to be recognized by a mass audience. (p. 312)

Because of this, the youth celebrity killer leaves nothing to mediated chance. The preparation for the act is obsessively documented so as to be publicized. Eric Harris and Dylan Klebold produced homemade video tapes self-reflexively musing on the celebrity potential of their actions. Only a handful of journalists have seen the tapes but two Time reporters wrote of them: They wanted movies made of their story, which they had carefully laced with 'a lot of foreshadowing and dramatic irony,' as Harris put it. There was a poem that he wrote, imagining himself as a bullet. 'Directors will be fighting over this story,' Klebold said and the boys chewed over which could be trusted with the script: Steven Spielberg or Quentin Tarantino. 'You have two individuals who wanted to immortalize themselves,' says [FBI agent Mark] Hostlaw. 'They wanted to be martyrs and to document everything they were doing.' (Gibbs \& Roche, 1999)

Presaging the impulse of Web 2.0 they further assembled a web page that announced to the Deleted: at pre-dot.com bust moment Deleted: $\mathrm{T}$ world their intentions and targets (Samuels, 2000). Harris visually modeled a Doom character's pose, chugging Jack Daniels with a sawed-off shotgun, in the tapes. They remarked how audiences would retrospectively marvel at the time and date of the tapes they were making. In that, their actions were not only premeditated (planned in advance), they were effectively "premediated" (packaged in advance). That is, their strategy encompassed both the preparations for the act itself as well as contingencies for the media circus they knew that would unfold around it. Neither Spielberg nor Tarantino took the bait, but Gus Van Sant loosely dramatized Columbine

Deleted: pre-mediatated

Deleted: $\mathrm{T}$

\begin{tabular}{l} 
Deleted: o \\
Deleted: : \\
Deleted: postmodern \\
Deleted: Zandt \\
\hline
\end{tabular}


in his film, Elephant, and P. J. Paparelli's play, Columbinus, toured the country to glowing reviews (Larkin, p. 194).

In the midst of his own rampage on April 16, 2007, Seung-Hui Cho similarly took time out to attend to public relations, sending NBC News a multimedia package that included a 1,800 word manifesto, 43 photographs and 25 minutes of videotape. As one forensic scientist and consultant to ABC News argued, "These videos do not help us understand him. They distort him. He was meek. He was quiet. This is a PR tape of him trying to turn himself into a Quentin Tarantino character" (ABC News, 2007). Furthermore, some had initially presumed that two of Cho's iconic photos - posed menacingly with a hammer and with a gun pressed to his head were visually quoting the film Oldboy, in which a Korean takes revenge through violent rampage (the latter of which was itself referencing Taxi Driver). Stephen Hunter adds that "much of the iconography in the photo gallery quotes poses in films by Hong Kong action director John Woo, as in the images where Cho holds two guns in his hands or points a gun at a camera" (in Kellner, 2008, p. 40).

Delving further into Cho's past, the Virginia state review panel tasked with producing a report on the shootings revealed earlier traces of Cho's hunger for celebrity. His sister reported on Cho's failed efforts to publish a novel and the disappointment that came with that rejection from a New York publisher. Roger L. Depue, a forensic behavioral scientist profiling Cho for the panel, wrote that in his sophomore year Cho discovered what he thought was "his niche, his special talent that would set him apart from the sea of other students at the university" (i.e. seeking the singularity - the disaggregation - of fame): writing (VT Review Panel N-3, 2007). Yet the publisher's rejection likely left him "devastated." Depue's report proceeds from the Deleted: That notion that fame drives murderous actions like Cho's from the very inception: Because of mental 
disorders, "[shooters] have come to the realization that they will never become important persons...memorable persons in history" (p. 1). Documenting their plans in essays and journals, these assassins "want to make sure that history records their most significant event" - they seek in short, the lure of celebrity immortality and diagram with increasing precision and multimedia interactivity how that obituary might be penned. Yet "Cho's dream was slipping away because of people - people who could not see and appreciate his desperate need to be recognized as somebody of importance" (p. 4). He fantasized solidarity with Eric (Harris) and Dylan (Klebold) on a first-name basis, but sought to do them one better: As the author of the "greatest school massacre ever," he would "go down in history" as "the savior of the oppressed" (p. 5). Cho's

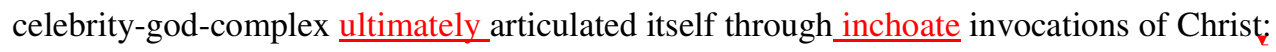
“Thanks to you, I die like Jesus Christ, to inspire generations" (Keller, p. 41).

Cho's effort to write himself into history took not only textual but also bodily form: He hoped that media would record his notoriety and that disciples would march in his footsteps, much as he did the Columbine perpetrators. Copycat panic immediately emerges to certify this. A high school student was arrested in Arkansas after writing of Cho’s heroism; an Internet posting threatened to kill 50 San Diego State students; and an entire Northern California school district shut down when a threat was made to "dwarf" the Virginia Tech violence (Hoffman, 2007). A former FBI agent claimed on MSNBC that: "This is what this guy [Cho] wants... He wants to... make us listen to him one more time" (p. A18). Indeed, the celebrity youth shooter pre-mediates by seeking to choreograph his or her own performance publically; they act out terror scripts authored in advance and try to direct the coverage that emerges by furnishing userDeleted: $\mathrm{s}$ Deleted: written generated content that subsidizes the mass media. In earlier eras, that celebrity youth shooter

Deleted: own

Deleted:

Deleted: ,

Deleted: kind of

Deleted: will
Deleted: The lineage of youth shooter in that regard seems to suggest selfperpetuating celebrity fertility: standing on the shoulders of savages who've gone before them helping those who would follow.

Deleted: internet Deleted: Students Deleted: ;

Deleted: these among many other threats and incidents 
had the gateway barrier of old media distribution; that Cho, in 2007, felt the need to package a

multimedia P.R. kit for NBC seemed technologically anachronistic for the time. With the

emergence and proliferation of self-published, online amateur content in the past decade, a kind

Deleted: even

of celebrity anarchy has ensued. The youth terrorist can now be actor, director and distributor. It is for this reason that Pekka-Eric Auvinen came to be known popularly as the "YouTube" killer: He demonstrates a disturbing devolution of the mash-up ethos; his cyber-evidence bespeaks the dark potential of Web 2.0. Writing of digital bodies and youth violence, Carolyn Guertin (2008) cautions:

The more we live connected in virtual worlds (in our minds or online) and disconnected from the real world the greater the potential mismatch between our egos and ourselves... The user-generated content revolution of Web 2.0, which includes blogging and other social network lifestyles, is in short fostering a new kind of egomania. (p. 222)

If Cho's egomania - fertilized by the current climate of technology and celebrity compelled him to deliver a packaged narrative to NBC, Auvinen knew that he could land on countless screens without needing a broadcast network intermediary. Relative to youth shooter precedence, his online presence was prolific. He wrote in English rather than Finnish to no

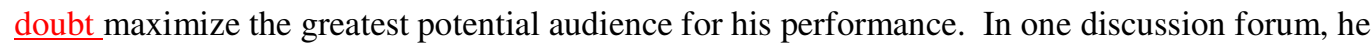
announced, "I want this to be remembered forever. Maybe I'll get followers too. Because I am an ubermench, nearly a god." Several hours after the shooting, YouTube suspended his account but one-quarter of a million people had already visited it by then and his mash-up creations are not hard to track down on the Web. His diary and online postings outline a noxious - and jumbled - brew of fascist, misogynist, and misanthropic ramblings from a self-described "cynical existentialist, antihuman humanist, antisocial social Darwinist, realistic idealist, and 
godlike Atheist." He explicitly sympathized with the Columbine killers and wrote gleefully of Cho's actions in the aftermath of Virginia Tech. Just hours prior to his own rampage, he posted a home-made video to YouTube titled, "Jokela High School Massacre - 11/7/2007" - again, not only signaling premeditation (police say the attack was eight months in planning) but also premediation; Auvinen sought to script his own spectacle in advance.

Deleted: mediatation Deleted:

Deleted: pastiche Deleted: bitterly shares a mash-up, omnivorous, darkly ironic texture. There are scenes of Auvinen blowing an apple to pieces with a handgun in the woods (and, crucially, mugging for the camera afterward). Title cards scroll through vague, offensive screeds: "Gods \& religious morals: Created by delusional/manipulative human beings to control the masses. Were created in the time without high level of technology and developed scientific research." "Humanity: ...is overrated and something I hate very much." "Women: Mmmm, I love them (of course because I'm straight) though most of them are cheating whores, lying sluts, and manipulative bitches. They are best when they are dominated, tied \& gagged." "Democracy: Dictatorship of the moral majority which is manipulated by the state mafia." "Political correctness: Lame." "Morals: ... are relative!" He narrates sadomasochistic fantasies with a Nazi tinge and punctuates them with Deleted: ; pornographic clips of women bound and gagged. He captures his own video game footage from Hitman of his character strangling women and re-cuts it with excerpts from a Discovery Channel docudrama of Columbine. There is pastiche homage to famous killers and assassins throughout history and a clip assembling footage from the media materials and coverage of the 1997 
Heaven's Gate suicide cult. And, taking the viewer fully through the Baudrillardian lookingglass, he re-casts Natural Born Killers images with a Motorhead track, "Born to Raise Hell" the film itself originally meant to serve as satirical commentary on violence and celebrity, but Auvinen appears to ironically appropriate the message. The clip "Videography1" contains the most densely textured and hyper-referential pace of any of the edited creations; it jis a collage of many of the other mash-ups from his hard drive, breathlessly cycling through; Finnish natural Deleted: with postmodern plunder landscapes; Hitler rallies; first-person shooter game scenes; serial killer mug-shots; religious iconography; The Matrix footage; military weaponry and war destruction; propaganda posters and consumer culture brands; Columbine reenactments; dictator portraits; heavy metal band logos; and his own enraged title card musings.

Virtuoso as "Videography1" seems intended to be, the clip "NaturalSelector891" offers perhaps the most concise glimpse into Auvinen's mash-up sensibility. The audio track plays the Alice Cooper tune, "Wicked Young Man" and as the base chugs toward the chorus ("It's not the games that I play / The movies I see / The music I dig / I'm just a vicious young man"), we see spliced clips successively synchronized to those lyrics from a first-person shooter video game, a machine gun shootout from A View to a Kill, the logo for German industrial rock band KMFDM, and a photo of Auvinen himself. As a message no doubt meant to be understood posthumously, he's almost talking back to the social conservative critique that opened this paper - reclaiming power, agency, accountability - and making the notoriety his own rather than allowing these famous media texts to hog his spotlight. Parts of his writings testify to this openly: "Remember that this is my war, my ideas and my plans. Don't blame anyone else for my actions than myself. Don't blame my parents or my friends... [Then quoting Cooper explicitly:] Don't blame the movies I see, the music I hear, the games I play or the book I read.” Auvinen wants shooter 
celebrity all to his own; he obsessively stresses that he alone authored this spectacle, this project that "discriminates him from the common herd of mortals." He knows how the script might be written (the media caused him) and - offering up user-generated content, doing the back story prep work for the press that would follow - seems to want to reverse the equation (he caused the media). This demonstrates the uneasy negotiation of fame-seeking through such self-published content: He is reliant upon the popular culture of the mass media but not wanting to be fully absorbed by it. He wants to make a name for himself, but can't articulate a statement that is not but the hodgepodge of texts whose own fame predates (and will succeed) him. If the story of

Deleted: succeeds Auvinen is written as the effect of industrial rock, violent video games or Oliver Stone films, Auvinen loses his grip on singularity, ubiquity, immortality - he remains a footnote of a celebrity. His cause would be lost; his spectacle subsumed; his fame cut short.

\section{Gatekeeping, Interrupted}

As Kellner astutely notices of Virginia Tech:

As the media spectacle unfolded during the first days, it was generally overlooked that the massacre could be seen as an attempt by Cho to act out some of his violent fantasies and create a media spectacle in which he appears as producer, director, and star. (p. 37)

French theorist Guy Debord (1995) observes that the concept of "spectacle" seems to explain much of modern life - particularly society's descent into being organized by and through images, stages, and commodities: "All that once was directly lived has become mere representation" (p. 142). Kellner builds on Debord - fused with Daniel Dayan and Elihu Katz's (1992) “media event" model - to argue for the emergence of "interactive spectacle" in the wake of participatory worlds and platforms in cyberspace. The tragedy of Jokela very much played out in the manner of an interactive spectacle: Auvinen's active, "prosumer" engagement with media text and his

Deleted: decent

Deleted: The whole life of those societies in which modern conditions of production prevail presents itself as an immense accumulation of spectacles. 
worldwide online audience's interactive engagement with that product. (More than one mash-up of Auvinen's mash-up appeared online.) The timeworn crime cliché, "getting away with it," traditionally means not being seen and hence not getting caught; for Auvinen, as well as Cho and the Columbine perpetrators, not being seen would've meant that he didn't get away with it.

And would the press comply? This seems to be the ethical question journalism has to confront in moving forward. Elihu Katz and Tamar Liebes (2007) recently updated the concept of "media event" to correspond with the rise of live broadcasts of disaster, terror and war. They suggest that the mobility and ubiquity of new media technology enables more unscheduled programming disruption than ever before: "If ceremonial events may be characterized as 'coproductions' of broadcasters and establishments, then disruptive events may be characterized as 'co-productions' of broadcasters and anti-establishment agencies, i.e. the perpetrators of disruption" (p. 157). Journalism will struggle over complicity with the youth killer shooting for fame. What ethics and practices will emerge as technologies and networks spawn more usergenerated content more quickly by those who stand accused of crime? At present, it appears that journalism is torn between competing impulses in the wake of a school shooting tragedy (particularly a school shooting tragedy whereby the killer furnishes a multimedia P.R. package via snail-mail or online).

On one hand, journalism - operating in the wake of trauma - feels its reparative calling. Carolyn Kitch (2003) shows how, in the aftermath of September 11, journalism assumed the role of civil religion, reaffirming group values and giving news stories moral and existential coherence and inflection. It affords closure, normalcy, reassurance (Vincent, Crow \& Davis, 1989); it tries to "serve simultaneously as conveyor, translator, mediator, and meaning-maker" (Zelizer \& Allan, 2002, p. 2). Cho and Auvinen very deliberately tried to circumvent this
Deleted: In crime,

Deleted: usually

Deleted: (

Deleted: )

Deleted: Christopher Smit (2001) applies Umberto Eco's idea of "hyperreality" to help explain Columbine: "The fabricated artifact (artistic, cultural, or natural) takes precedence over daily reality; the hyperreal offers a realism that truncates daily reality and offers a phenomenon that will never be matched by the experience of daily life" (p. 90). Unable to see the satire in Natural Born Killers, Auvinen sought to generate his own hyperreality that might be overlaid upon his act; this YouTube killer issued a mash-up communiqué that bespoke both premeditation and pre-mediatation.

Deleted: W

Deleted: struggles 
institutional interlocutor; they labored to narrate their own spectacle, to provide notes in the margins of the first draft of history, to talk over and past the "interpretive community" that they knew would try to absorb them to bring their act back into the fold (Zelizer, 1993).

Nevertheless, in the wake of Jokela, the reparative template was put in motion. The headline of Aamulehti, Finland's second largest newspaper, the day after the shooting? Together. "That was the main lesson that week," Matti Posio, an editor at the paper, told me in an interview. "That you have to be together like an incident like that."

Yet that togetherness is not always shared by the community with the media. Neil King (2008) comments on the "siege frame of mind" that Blacksburg locals developed in reaction to the intense exposure - the blinding glare of fame's klieg lights that Cho had brought upon his campus. Hand-scrawled fliers told camera crews to go home ("Hokie nation needs to heal. Media stay away") and the university administration told reporters to vacate campus buildings. An e-mail petition requested:

We are Hokie Nation and we need to mourn and heal. We need each other. The media has taken advantage of our situation and are exploiting us for their own sensationalism. We will not tolerate the abuse; we love our community far too much to stand for this any more. We, the students of Virginia Tech, are asserting ourselves. We are taking back our campus. All media, if they have any respect for Hokie Nation, will no longer attack the administration. They will no longer hound our students. Leave us to heal. Leave us to ourselves. Hokie Nation needs to be UNITED. Return our campus to us. (Kellner, 2008, p. 181)

If Cho had deprived reporters of part of their task of investigative reporting (furnishing some of his back story), locals seemed to be depriving reporters of their self-appointed calling to be 
mythic healers. "In the aftermath of group death, professional norms require reporters to swarm the living and shoot footage of anyone choked with emotion. The rapid progress of events impels them to gain access quickly, via entreaty and intrusion," King writes (p. 56). "Many locals spoke in grim humor of the cameras and boom mikes that hovered when mourners neared tears. Reporters grew aware of this reaction to their work and made enquiries in the hushed tones of undertakers." Theirs was an invasion of "sacred space" - a frenzied intrusion to remediate grief by and through public consumption. Jokela experienced jts own deluge of media Deleted: also attention and, interestingly, responded with a backlash of its own. When an estimated 100 journalists - both domestic and international - descended on this town of 5,000, the collision seemed inevitable. By the end of the week, 2,000 citizens had signed a petition criticizing the media's handling of the tragedy. About a half-dozen Finnish media outlets either had links to Auvinen's online videos or directly hosted them. Questions abounded within newsrooms as to whether this was "giving in" to Auvinen's posthumous demands. "I don't think that killing itself is the point for the killer," said Bjorksen Tuomo, a reporter for Aamulehti who covered the story as a feature. "It must be somehow related to the fame - when you kill so many people, it's rather about showing to the world that I did this rather than the actual killings themselves."

\section{Copycat Postscript}

As it tragically turns out, Auvinen was not the last YouTube content creator-turned-

Deleted: school shooter school shooter in Finnish history. In September 2008, a 22-year-old vocational student killed himself and 10 people; shortly before, he had posted an online video in which he pointed a gun at the camera and announced, "You will die next."

Seung-Hui Cho and Pekka-Eric Auvinen visited a terror upon their respective schools that was not only premeditated (violence calculated in advance) but also "pre-mediated" 
(direction packaged in advance). Crime has long been accompanied by attempts by the

perpetrator to sway coverage of the act: think of the terrorist communiqué or serial killer sending

letters to press. Today, the low cost of video production technology and the ease of network

distribution means that (anti-)social media can be generated easier than ever. Much of the

rhetoric surrounding user-generated content springs from a hopeful, empowered archetype; as

when Time magazine declared its 2006 "Person of the Year" "You" - the amateur-revolutionary

at the heart of Web 2.0 - "for seizing the reins of global media, for founding and framing the

new digital democracy, for working at nothing and beating the pros and their own game"

(Grossman, 2006). Auvinen betrays a much darker potential for these tools in that flattened

landscape; his handiwork heralds the possibility that if "Generation Mash-Up" can't achieve

fame by cutting and splicing media texts to refashion expressive, often ironic commentary

Deleted: -

infamy is no less self-mediated (Serazio, 2008). The ever-increasing supply of amateur content

populating the Web means that, when the next school shooting does arrive, there is a fairly

decent chance that journalists - and all online audiences, really - will find a cyber-trail of

hyperlinked, hybridized, media-saturated presentations of the self. If the youth killer's diary was

once only open to reporters at the crime scene, the youth killer's blog is a much more open book.

For the terrorist of Jokela High School, the shooting started well before that fateful morning. ${ }^{5}$

.

\footnotetext{
${ }^{5}$ Part of the argument for this paper appeared in a briefly summarized form in the online magazine, Flow.
}

\begin{tabular}{|c|}
\hline $\begin{array}{l}\text { Deleted: In that, the ethical question for } \\
\text { journalistic reportage may increasingly be } \\
\text { irrelevant. And to narrow the debate over } \\
\text { blame to specific media texts might be } \\
\text { missing the forest for the trees when } \\
\text { those texts themselves are poached and } \\
\text { scrambled and reconstructed with savage } \\
\text { bricolage by very active youth audiences } \\
\text { who are nonetheless influenced by a } \\
\text { general framework around fame. }\end{array}$ \\
\hline $\begin{array}{l}\text { Deleted: II } \\
\text { II } \\
\text { II } \\
\text { II } \\
\text { II } \\
\text { II } \\
\text { II } \\
\text { II } \\
\text { II } \\
\text { II } \\
\text { II } \\
\text { II } \\
\text { II } \\
\text { II } \\
\text { II }\end{array}$ \\
\hline
\end{tabular}




\section{References}

ABC News. (2007, April 19). Psychiatrist: Showing video is social 'catastrophe'. Retrieved

October 27, 2008 from http://abcnews.go.com/GMA/VATech/story?id=3056168

Best, S., \& Kellner, D. (2003). Contemporary youth and the postmodern adventure. Review of Education/Pedagogy/Cultural Studies, 25(2), 75-93.

Boorstin, D. (1987). The image: A guide to pseudo-events in America. New York: Atheneum.

Braudy, L. (1986). The frenzy of renown: Fame and its history. Oxford: Oxford University Press.

Brooker, W., \& Jermyn, D. (Eds.). (2003). The audience studies reader. London: Routledge.

Bruns, A. (2008). Blogs, wikipedia, second life, and beyond: From production to produsage. New York: Peter Lang.

Cowen, T. (2000). What price fame? Cambridge: Harvard University Press.

Dayan, D., \& Katz, E. (1992). Media events: The live broadcasting of history. Cambridge, MA: Harvard University Press.

Debord, G. (1995). The society of the spectacle. New York: Zone Books.

Deuze, M. (2007). Media work. Cambridge: Polity.

Gibbs, N., \& Roche, T. (1999, December 200). The Columbine tapes. Time.

Giles, D. (2000). Illusions of immortality: A psychology of fame and celebrity. London: Macmillian.

Goffman, E. (1959). The presentation of self in everyday life. New York: Anchor Books.

Gold, M. (2007, April 19). In the media: Gunman handed NBC an exclusive and a quandary. Los Angeles Times, p. A18. 
Grossman, L. (2006, December 13). Time's person of the year: You. Time.com. Retrieved December 3, 2007, from http://www.time.com/time/magazine/article/0,9171,1569514,00.html

Guertin, C. (2008). All the rage: Digital bodies and deadly play in the age of the suicide bomber. In B. Agger \& T. W. Luke (Eds.), There is a gunman on campus: Tragedy and terror at Virginia Tech (pp. 213-228). Lanham, MD: Rowman \& Littlefield.

Gritten, D. (2002). Fame: Stripping celebrity bare. London: Allen Lane.

Hartlaub, P. (2007, April 24). Another tragedy, another platform for video game fearmonger. The San Francisco Chronicle, p. D1.

Hoffman, A. (2007, April 19). School threats sweep country. The San Francisco Chronicle, p. TK.

Horkheimer, M., \& Adorno, T. (1977). The culture industry: Enlightenment as mass deception. In J. Curran, M. Gurevitch, \& J. Woollacott (Eds.), Mass communication and society (pp. 349-383). Beverly Hills, CA: Sage.

Jenkins, H. (2006). Convergence culture: Where old and new media collide. New York: NYU Press.

Katz, E. (2001). Media effects. International encyclopedia of the social and behavioral sciences (pp. 9472-9479). Oxford: Elsevier Science.

Katz, E., \& Liebes, T. (2007). 'No more peace!': How disaster, terror and war have upstaged media events. International Journal of Communication, 1, 157-166.

Kellner, D. (2008). Guys and guns amok: Domestic terrorism and school shootings from the Oklahoma City bombing to the Virginia Tech massacre. Boulder, CO: Paradigm. 
Kimmel, M. (2008). Profiling school shooters and shooters' schools: The cultural contexts of aggrieved entitlement and restorative masculinity. In B. Agger \& T. W. Luke (Eds.), There is a gunman on campus: Tragedy and terror at Virginia Tech (pp. 65-78). Lanham, MD: Rowman \& Littlefield.

King, N. (2008). Mediated ritual on academic ground. In B. Agger \& T. W. Luke (Eds.), There is a gunman on campus: Tragedy and terror at Virginia Tech (pp. 55-64). Lanham, MD: Rowman \& Littlefield.

Kitch, C. (2003). "Mourning in America": ritual, redemption, and recovery in news narrative after September 11. Journalism Studies, 4(2), 213-224.

Larkin, R. W. (2007). Comprehending Columbine. Philadelphia: Temple University Press.

Marshall, P. D. (1997). Celebrity and power: Fame in contemporary culture. Minneapolis: University of Minnesota Press.

McCombs, M. E., \& Shaw, D. L. (1972). The agenda-setting function of mass media. Public Opinion Quarterly, 36, 176-187.

McLuhan, M. (1964). Understanding media: The extensions of man. Cambridge: MIT Press. Morgan, M., Shanahan, J., \& Signorielli, N. (2009). Growing up with television: Cultivation processes. In J. Bryant \& M. B. Oliver (Eds.), Media effects: Advances in theory and research (pp. 34-49). New York: Routledge.

Muschert, G. W. (2007). Research in school shootings. Sociology Compass, 1(1), 60-80.

Pew Research Center. (2007, January 9). How young people view their lives, futures and politics: A portrait of generation 'next'. Washington, DC: Pew Research Center.

Rojek, C. (2001). Celebrity. London: Reaktion Books. 
Samuels, R. (2000). From Columbine to professional wrestling: A psychoanalysis of postmodern media violence. Journal for the Psychoanalysis of Culture \& Society, 5(2), 312-318.

Seiter, E. (1999). Television and new media audiences. Oxford: Oxford University Press.

Serazio, M. (2008). The apolitical irony of Generation Mash-Up: A cultural case study in popular music. Popular Music and Society, 31(1), 79-94.

Smit, C. R. (2001). Columbine: An exploration of the hyperreal in televisual chaos. In R. B. Browne \& A. B. Neal (Eds.), Ordinary reactions to extraordinary events (pp. 88-101). Bowling Green, OH: Bowling Green State University Popular Press.

Stein, H. F. (2000). Disposable youth: The 1999 Columbine high school massacre as American metaphor. Journal for the Psychoanalysis of Culture and Society, 5(2), 217-236.

Turner, G. (2004). Understanding celebrity. London: Sage.

Twenge, J. M. (2006). Generation me. New York: Free Press.

Vincent, R. C., Crow, B. K., \& Davis, D. K. (1989). When technology fails: The drama of airline crashes in network television news. Journalism Monographs, 117.

VT Review Panel N-3. (2007). A theoretical profile of Seung Hui-Cho. Retrieved October 27, 2008 from http://www.vtreviewpanel.org/report/report/32_APPENDIX_N.pdf

Zelizer, B. (1993). Journalists as interpretive communities. Critical Studies in Mass Communication, 10(3), 219-237.

Zelizer, B., \& Allan, S. (2002). Introduction: When trauma shapes the news. In B. Zelizer \& S. Allan (Eds.), Journalism after September 11 (pp. 1-24). London: Routledge. 